\title{
Maternal and embryonic gene effects on placental weight in mice
}

\author{
Ann Blakley* \\ Department of Zoology, University of Iowa, Iowa City, Iowa 52242, U.S.A.
}

\begin{abstract}
Summary. Placental weight was measured on Days 12 and 18 of pregnancy in a population of mice consisting of two inbred strains and their derived generations. Maternal and embryonic genotypes influenced placental weight, the maternal genotypic effects changing with the stage of pregnancy. Effects of specific maternal and embryonic genotypes are discussed in terms of possible influence on the growth of maternally and embryonically derived placental tissues throughout pregnancy. Genotype-dependent differences in placental weight could not be accounted for simply by the presence or absence of $\mathrm{H}-2$ antigenic differences between mothers and embryos. On Day 18 male embryos had heavier placentae than female embryos. The correlation between embryonic weight and placental weight declined in some mating groups from 12 to 18 days, suggesting differential placental weight loss late in pregnancy.
\end{abstract}

\section{Introduction}

The placenta is a component of the uterine environment in which mammalian embryos develop and could be affected by maternal and embryonic genotypes, since it is composed of tissues from both sources. Because the placenta is the major site of exchange of materials between mother and embryo, any maternal or embryonic gene differences resulting in differences in placental size may alter the uterine environment and influence the processes of embryonic growth and development.

Gene effects on placental weight are not well understood. In the mouse $F_{1}$ embryos derived from crossing inbred strains have been reported to have heavier placentae than corresponding inbred embryos (Billington, 1964; James, 1965; McCarthy, 1965; McLaren, 1965a; Hetherington, 1971). Hetherington (1973) has suggested that increased $F_{1}$ placental weight results from heterosis, and this suggestion is consistent with the inference of McCarthy (1968) that rapid inbreeding decreases placental weight. One way in which $F_{1}$ placental weight might be increased is through the existence of H-2 antigenic differences between mother and embryo, as Billington (1964) and James (1965) have suggested. However, research with congenic resistant strains of mice has failed to demonstrate increased placental weight when mothers and embryos differ from one another only at the $\mathbf{H}-2$ or $\mathbf{H}-3$ locus (Finkel \& Lilly, 1971; Hetherington, 1973). Furthermore, increased $F_{1}$ placental weight is not universally observed. In crosses involving strain JU mothers, weights of $F_{1}$ placentae were either less than or not significantly different from those of inbred JU mice (McCarthy, 1965; McLaren, 1967; Hetherington, 1971).

The purposes of the work reported in this paper were (1) to examine the effects of maternal and embryonic genotypes on placental weight by comparing the effects of inbred, $F_{1}$, and segregating genotypes on placental weight in mice, and (2) to determine the relation between placental weight and embryonic weight at two stages of development, (a) when embryos and placentae are both growing rapidly and (b) later, when placental growth has ceased, but embryonic growth continues.

\section{Materials and Methods}

\section{Experimental design}

Female mice of the inbred strains $\mathrm{C} 3 \mathrm{H} / \mathrm{HeJ}$ and DBA/1 J (subsequently called $\mathrm{C} 3 \mathrm{H}$ and DBA), their reciprocal $\mathrm{F}_{1}$ hybrids, $\mathrm{C} 3 \mathrm{H} \times \mathrm{DBA}$ and $\mathrm{DBA} \times \mathrm{C} 3 \mathrm{H}$ (hereafter designated $\mathrm{CD}$ and DC with

* Present address: Institute of Animal Genetics, West Mains Road, Edinburgh EH9 3JN, U.K. 
the strain of female parent listed first), and $\mathrm{F}_{2}$ generation were mated to $\mathrm{C} 3 \mathrm{H}, \mathrm{DBA}, \mathrm{CD}, \mathrm{DC}$ or $\mathrm{F}_{2}$ males to produce inbred, reciprocal $F_{1}$ hybrid, reciprocal backcross, $F_{2}$ and $F_{3}$ litters as shown in Table 1.

Table 1. Genotypes and designations of mouse litters from strains $\mathrm{C} 3 \mathrm{H} / \mathrm{HeJ}$ and DBA/1J and their derived generations

\begin{tabular}{|c|c|c|c|c|c|}
\hline \multirow{2}{*}{$\begin{array}{l}\text { Genotype of } \\
\text { female parent }\end{array}$} & \multicolumn{5}{|c|}{ Genotype of male parent } \\
\hline & $\mathrm{C} 3 \mathrm{H}$ & DBA & $\mathrm{CD}$ & $\mathrm{DC}$ & $\mathbf{F}_{\mathbf{2}}$ \\
\hline $\mathrm{C} 3 \mathrm{H}$ & $\begin{array}{l}\mathrm{C} 3 \mathrm{H} \\
\text { (inbred) }\end{array}$ & $\begin{array}{l}C D \\
\left(F_{1}\right)\end{array}$ & $\begin{array}{l}\mathrm{C} 3 \mathrm{H} \times \mathrm{CD} \\
\text { (backcross) }\end{array}$ & $\begin{array}{l}\mathrm{C} 3 \mathrm{H} \times \mathrm{DC} \\
\text { (backcross) }\end{array}$ & - \\
\hline DBA & $\begin{array}{l}\mathrm{DC} \\
\left(\mathrm{F}_{1}\right)\end{array}$ & $\begin{array}{l}\text { DBA } \\
\text { (inbred) }\end{array}$ & $\begin{array}{l}\mathrm{DBA} \times \mathrm{CD} \\
\text { (backcross) }\end{array}$ & $\begin{array}{l}\mathrm{DBA} \times \mathrm{CD} \\
\text { (backcross) }\end{array}$ & - \\
\hline CD & $\begin{array}{l}\mathrm{CD} \times \mathrm{C} 3 \mathrm{H} \\
\text { (backcross) }\end{array}$ & $\begin{array}{l}\mathrm{CD} \times \mathrm{DBA} \\
\text { (backcross) }\end{array}$ & $\mathbf{F}_{\mathbf{2}}$ & $\mathbf{F}_{2}$ & - \\
\hline DC & $\begin{array}{l}\mathrm{DC} \times \mathrm{C} 3 \mathrm{H} \\
\text { (backcross) }\end{array}$ & $\begin{array}{l}\mathrm{DC} \times \mathrm{DBA} \\
\text { (backcross) }\end{array}$ & $\mathbf{F}_{2}$ & $\mathbf{F}_{\mathbf{2}}$ & - \\
\hline $\mathbf{F}_{\mathbf{2}}$ & - & - & - & - & $\mathbf{F}_{\mathbf{3}}$ \\
\hline
\end{tabular}

The $F_{2}$ animals were derived from all four possible crosses of reciprocal $F_{1}$ parents.

The effect of maternal genotype on placental weight was determined by pooling placental weights from embryos sired by males of various genotypes within each genotype of female and comparing these pooled data across genotypes of female. The effect of embryonic genotype was determined by comparing placental weights from different embryonic gentoypes within each genotype of female.

\section{Experimental procedures}

Virgin females, $60-70$ days old, were weighed to the nearest $0 \cdot 1 \mathrm{~g}$ at the time of mating to males of the appropriate genotype. The day on which a vaginal plug was found was considered Day 1 of pregnancy. Females were killed by cervical dislocation on Day 12 or Day 18 and dissected. Embryos and placentae were removed from the uterus, freed from their membranes, blotted gently, and weighed to the nearest $0.1 \mathrm{mg}$. In addition, the sex of 18-day embryos was recorded. Litters which were not at the expected stage of development at the time of dissection, according to criteria of Theiler (1972), were discarded. Measurements of 18-day embryos and placentae of all mating groups were performed contemporaneously and were completed before measurements of 12-day embryos and placentae were started.

\section{Data analysis}

Means and standard errors in Tables 2 and 3 were computed from litter means. Means were compared with the Student-Newman-Keuls multiple range test (Sokal \& Rohlf, 1969), and significance levels given in the text refer to the results of this test. The placental means for male and female embryos (Table 4) are individual means and were compared within mating groups by Student's $t$ test. The correlations between embryonic weights and placental weights in Table 5 are pooled within mothers and mating groups.

\section{Results}

The effect of maternal genotype on placental weight changed from Day 12 to Day 18 of pregnancy (Table 2). On Day 12 there were no significant differences among the weights of placentae from $\mathrm{C} 3 \mathrm{H}$, $C D$ and DC females, all of which were significantly heavier than placentae from DBA females, indi- 
cating that the $\mathrm{C} 3 \mathrm{H}$ maternal genotype was dominant over the DBA maternal genotype with respect to placental weight. The mean weight of placentae from $F_{2}$ mothers did not differ significantly from those of $\mathrm{C} 3 \mathrm{H}$ and $\mathrm{F}_{1}$ placentae. In contrast, on Day $18 \mathrm{DBA}$ mothers had significantly heavier placentae $(P<0.01)$ than $\mathrm{C} 3 \mathrm{H}, \mathrm{CD}$ and DC mothers who again did not differ significantly from one another. The $\mathrm{F}_{2}$ maternal mean, although not significantly different from the $\mathrm{C} 3 \mathrm{H}$ maternal mean, did differ from the means for the $F_{1}$ mothers, possibly indicating effects of segregation at this time.

Table 2. Mean maternal body weights ( \pm s.e.m.), litter sizes $( \pm$ s.e.m.) and litter mean ( \pm s.e.m.) placental weights on Days 12 and 18 of pregnancy according to the genotype of the mother

\begin{tabular}{|c|c|c|c|c|c|c|c|}
\hline \multirow[b]{2}{*}{$\begin{array}{l}\text { Genotype } \\
\text { of mother }\end{array}$} & \multirow[b]{2}{*}{$\begin{array}{l}\text { Body } \\
\text { wt (g) }\end{array}$} & \multicolumn{3}{|c|}{ Day 12} & \multicolumn{3}{|c|}{ Day 18} \\
\hline & & $\begin{array}{l}\text { No. of } \\
\text { litters }\end{array}$ & $\begin{array}{l}\text { Litter } \\
\text { size }\end{array}$ & $\begin{array}{c}\text { Placental } \\
\text { wt (mg) }\end{array}$ & $\begin{array}{l}\text { No. of } \\
\text { litters }\end{array}$ & $\begin{array}{l}\text { Litter } \\
\text { size }\end{array}$ & $\begin{array}{c}\text { Placental } \\
\text { wt (mg) }\end{array}$ \\
\hline $\mathrm{C} 3 \mathrm{H}$ & $19 \cdot 2 \pm 0.2$ & 55 & $7.4 \pm 0.2$ & $47.9 \pm 0.6$ & 55 & $6.9 \pm 0.2$ & $104 \cdot 7 \pm 1 \cdot 1$ \\
\hline DBA & $16.7 \pm 0.2$ & 52 & $6.6 \pm 0.3$ & $40.4 \pm 0.7^{*}$ & 54 & $7 \cdot 0 \pm 0.3$ & $119.7 \pm 1 \cdot 2^{*}$ \\
\hline $\mathrm{CD}$ & $20.2 \pm 0.2$ & 38 & $9.0 \pm 0.3$ & $49.0 \pm 0.5$ & 41 & $10.0 \pm 0.3$ & $99 \cdot 2 \pm 1 \cdot 1 \dagger$ \\
\hline DC & $18.7 \pm 0.2$ & 40 & $7.9 \pm 0.3$ & $49.4 \pm 0.5$ & 40 & $9.4 \pm 0.2$ & $101.7 \pm 1.5 \dagger$ \\
\hline $\mathbf{F}_{2}$ & $19.2 \pm 0.2$ & 21 & $8.9 \pm 0.3$ & $48.9 \pm 0.8$ & 19 & $8 \cdot 3 \pm 0 \cdot 4$ & $107 \cdot 0 \pm 2 \cdot 2$ \\
\hline
\end{tabular}

For each genotype of mother, the data have been pooled across genotypes of sire as indicated in 'Materials and Methods'.

* Significantly different from all other values at that stage, $P<0.01$.

+ These values significantly differed from the $F_{2}$ value $(t=2 \cdot 7$, d.f. $=97, P<0 \cdot 05)$.

Both maternal body weight and litter size varied among genotypes of mother (Table 2). Regression analyses were performed to determine whether differences in placental weights among genotypes of mothers could be accounted for by differences in body weight or in litter size. Regressions of litter mean placental weight on maternal body weight varied among mating groups but all were nonsignificant. Regressions of placental weight on litter size tended to be negative, as expected, but were also non-significant.

Table 3. Litter mean ( \pm s.e.m.) placental weights of mice at Days 12 and 18 of pregnancy according to the genotype of the embryo

\begin{tabular}{|c|c|c|c|c|}
\hline \multirow{2}{*}{$\begin{array}{c}\text { Genotype } \\
\text { of embryo } \\
\left(+\times \delta^{\prime}\right)\end{array}$} & \multicolumn{2}{|c|}{ Day 12} & \multicolumn{2}{|c|}{ Day 18} \\
\hline & $\begin{array}{l}\text { No. of } \\
\text { litters }\end{array}$ & $\begin{array}{l}\text { Placental } \\
\text { wt (mg) }\end{array}$ & $\begin{array}{l}\text { No. of } \\
\text { litters }\end{array}$ & $\begin{array}{l}\text { Placental } \\
\text { wt (mg) }\end{array}$ \\
\hline $\mathrm{C} 3 \mathrm{H}$ & 15 & $43 \cdot 6 \pm 1 \cdot 1$ & 15 & $92.5 \pm 2.4$ \\
\hline $\mathrm{CD}$ & 15 & $48.8 \pm 0.9$ & 15 & $117 \cdot 2 \pm 2 \cdot 1$ \\
\hline $\mathrm{C} 3 \mathrm{H} \times \mathrm{CD}$ & 13 & $49 \cdot 0 \pm 1.2$ & 12 & $103.2 \pm 1.9$ \\
\hline $\mathrm{C} 3 \mathrm{H} \times \mathrm{DC}$ & 12 & $50.5 \pm 1.9$ & 13 & $105 \cdot 6 \pm 2 \cdot 3$ \\
\hline DBA & 15 & $40 \cdot 3 \pm 1 \cdot 3$ & 15 & $122 \cdot 4 \pm 1 \cdot 2$ \\
\hline DC & 15 & $40 \cdot 1 \pm 1 \cdot 2$ & 15 & $117.9 \pm 2.5$ \\
\hline $\mathrm{DBA} \times \mathrm{CD}$ & 12 & $39 \cdot 6 \pm 1 \cdot 1$ & 12 & $121 \cdot 2 \pm 3 \cdot 2$ \\
\hline $\mathrm{DBA} \times \mathbf{D C}$ & 10 & $42 \cdot 1 \pm 1 \cdot 7$ & 12 & $117 \cdot 2 \pm 2 \cdot 6$ \\
\hline $\mathrm{CD} \times \mathrm{C} 3 \mathrm{H}$ & 12 & $47 \cdot 7 \pm 1 \cdot 1$ & 13 & $92 \cdot 8 \pm 2 \cdot 3$ \\
\hline $\mathrm{CD} \times \mathrm{DBA}$ & 12 & $51.2 \pm 1.6$ & 12 & $102.5 \pm 1.7$ \\
\hline $\mathrm{F}_{2}$ (CD mother) & 14 & $48 \cdot 1 \pm 0.8$ & 16 & $101.9 \pm 1.7$ \\
\hline $\mathrm{DC} \times \mathrm{C} 3 \mathrm{H}$ & 14 & $48.2 \pm 0.6$ & 16 & $91.4 \pm 2.4$ \\
\hline $\mathrm{DC} \times \mathrm{DBA}$ & 12 & $50 \cdot 1 \pm 1 \cdot 1$ & 14 & $105.4 \pm 2.0$ \\
\hline $\mathrm{F}_{2}$ (DC mother) & 14 & $50 \cdot 0 \pm 1 \cdot 1$ & 14 & $106 \cdot 7 \pm 3 \cdot 2$ \\
\hline$F_{3}$ & 21 & $48.9 \pm 0.8$ & 19 & $107 \cdot 0 \pm 2 \cdot 2$ \\
\hline
\end{tabular}


Effects of embryonic genotype varied according to the genotype of mother (Table 3). Within C3H mothers there was evidence for embryonic heterosis for placental weight because on Days 12 and 18 the $F_{1}$ and backcross placentae were significantly heavier $(P<0.01)$ than inbred placentae. The weights of $F_{1}$ and backcross placentae were not significantly different from one another on Day 12 , but $F_{1}$ placentae were heavier $(P<0.05)$ on Day 18 . Within DBA mothers, there were no significant weight differences among placentae of different genotypes on Days 12 or 18 , suggesting that the effect of the DBA maternal genotype masked effects of embryonic genotypes. Within $F_{1}$ mothers, backcross embryos sired by $\mathrm{C} 3 \mathrm{H}$ males had smaller placentae than those sired by DBA or $\mathrm{F}_{1}$ males although the differences were significant $(P<0.01)$ only on Day 18.

There was a consistent and significant effect of embryonic sex on placental weight on Day 18 (Table 4). Within each of the 15 mating groups examined, male embryos had significantly heavier placentae than females. There was no evidence for sex-linkage because there was no significant difference between the weights of reciprocal $F_{1}$ male placentae.

The effect of differences in placental weight on embryonic weight was examined by computing the correlation between embryonic weight and placental weight for each mating group (Table 5). On Day 12 when the embryos and placentae were growing rapidly, heavy embryos tended to have heavy placentae. This relation was significant in all but one of the mating groups (CD). On Day 18 all but 5 of the correlations were significantly positive. The average $r^{2}$ values indicate that variance in placental weight accounts for more of the variance in embryonic weight on Day 12 than on Day 18.

Table 4. Mean ( \pm s.e.m.) placental weight at Day 18 of pregnancy according to the genotype and sex of the embryo

\begin{tabular}{|c|c|c|c|c|c|c|}
\hline \multirow{3}{*}{$\begin{array}{l}\text { Genotype } \\
\text { of embryo }\end{array}$} & \multicolumn{2}{|r|}{ Females } & \multicolumn{2}{|r|}{ Males } & \multirow{2}{*}{\multicolumn{2}{|c|}{ Significance* }} \\
\hline & & Placental wt & & Placental wt & & \\
\hline & No. & (mg) & No. & (mg) & $t$ & $P$ \\
\hline $\mathrm{C} 3 \mathrm{H}$ & 38 & $85.3 \pm 1.8$ & 42 & $96 \cdot 1 \pm 2 \cdot 0$ & 3.98 & $<0.001$ \\
\hline $\mathrm{CD}$ & 62 & $111.5 \pm 1.8$ & 46 & $124 \cdot 1 \pm 2 \cdot 4$ & $4 \cdot 29$ & $<0.001$ \\
\hline $\mathrm{C} 3 \mathrm{H} \times \mathrm{CD}$ & 37 & $94.8 \pm 1.6$ & 44 & $109.8 \pm 1.9$ & $5 \cdot 91$ & $<0.001$ \\
\hline $\mathrm{C} 3 \mathrm{H} \times \mathrm{DC}$ & 42 & $98 \cdot 8 \pm 2.2$ & 46 & $111.6 \pm 1.8$ & $4 \cdot 53$ & $<0.001$ \\
\hline DBA & 38 & $114.0 \pm 5.6$ & 30 & $134 \cdot 1 \pm 4 \cdot 5$ & 2.69 & $<0.01$ \\
\hline $\mathrm{DC}$ & 47 & $110.9 \pm 24$ & 40 & $124 \cdot 7 \pm 2 \cdot 9$ & $3 \cdot 70$ & $<0.001$ \\
\hline $\mathrm{DBA} \times \mathrm{CD}$ & 36 & $115 \cdot 2 \pm 3.0$ & 48 & $127 \cdot 0 \pm 3 \cdot 1$ & $2 \cdot 67$ & $<0.01$ \\
\hline $\mathbf{D B A} \times \mathbf{D C}$ & 35 & $105.8 \pm 1.9$ & 38 & $122.9 \pm 3.4$ & 4.43 & $<0.001$ \\
\hline $\mathrm{CD} \times \mathrm{C} 3 \mathrm{H}$ & 64 & $86.9 \pm 1.6$ & 47 & $109.8 \pm 2.2$ & 8.63 & $<0.001$ \\
\hline $\mathrm{CD} \times \mathrm{DBA}$ & 63 & $97.5 \pm 1.4$ & 55 & $111.6 \pm 2.2$ & $5 \cdot 54$ & $<0.001$ \\
\hline$C D \times F_{1}$ & 69 & $95 \cdot 5 \pm 1 \cdot 4$ & 82 & $108.6 \pm 1.8$ & $5 \cdot 59$ & $<0.001$ \\
\hline $\mathrm{DC} \times \mathrm{C} 3 \mathrm{H}$ & 57 & $85.7 \pm 1.6$ & 55 & $97 \cdot 3 \pm 2 \cdot 3$ & $4 \cdot 16$ & $<0.001$ \\
\hline $\mathbf{D C} \times \mathbf{D B A}$ & 63 & $97.9 \pm 1.5$ & 48 & $110.7 \pm 1.7$ & $5 \cdot 64$ & $<0.001$ \\
\hline $\mathrm{DC} \times \mathrm{F}_{1}$ & 62 & $97.8 \pm 1.9$ & 64 & $111 \cdot 9 \pm 2 \cdot 0$ & $5 \cdot 11$ & $<0.001$ \\
\hline$F_{3}$ & 60 & $100 \cdot 5 \pm 2 \cdot 2$ & 96 & $115 \cdot 2 \pm 1 \cdot 7$ & $5 \cdot 32$ & $<0.001$ \\
\hline
\end{tabular}

* Compared by Student's $t$ test.

\section{Discussion}

In this population of mice, placental weight was influenced both by maternal and embryonic genotypes, and their effects changed during pregnancy. Although $\mathrm{C} 3 \mathrm{H}$ maternal genotype was dominant over the DBA maternal genotype with respect to placental weight on Days 12 and 18, the effect of each genotype was reversed between these times, $\mathrm{C} 3 \mathrm{H}$ and $\mathrm{F}_{1}$ mothers having heavier placentae than DBA mothers on Day 12 and lighter placentae on Day 18. On Day 12 the DBA maternal and embryonic genotype (strictly speaking, the sire genotype) appeared to exert opposite effects on placental weight, the maternal genotype apparently reducing placental weight relative to the $\mathrm{C} 3 \mathrm{H}$ maternal genotype 
Table 5. Pooled within-mother correlations between embryonic and placental weights on Days 12 and 18 of pregnancy

\begin{tabular}{|c|c|c|c|c|}
\hline \multirow{2}{*}{$\begin{array}{l}\text { Genotype } \\
\text { of embryo }\end{array}$} & \multicolumn{2}{|r|}{ Day 12} & \multicolumn{2}{|c|}{ Day 18} \\
\hline & d.f. & $r$ & d.f. & $r$ \\
\hline $\mathrm{C} 3 \mathrm{H}$ & 98 & $0 \cdot 28^{* *}$ & 65 & $0 \cdot 21^{*}$ \\
\hline CD & 92 & $0 \cdot 19$ & 93 & $0.33^{* *}$ \\
\hline $\mathrm{C} 3 \mathrm{H} \times \mathrm{CD}$ & 73 & $0.51^{* *}$ & 69 & $0.62^{* *}$ \\
\hline $\mathrm{C} 3 \mathrm{H} \times \mathrm{DC}$ & 84 & $0.49 * *$ & 75 & $0 \cdot 11$ \\
\hline DBA & 86 & $0.45^{* *}$ & 72 & $0.35^{* *}$ \\
\hline DC & 79 & $0.46^{* *}$ & 53 & 0.07 \\
\hline $\mathrm{DBA} \times \mathrm{CD}$ & 58 & $0.67^{* *}$ & 72 & 0.07 \\
\hline $\mathrm{DBA} \times \mathrm{DC}$ & 58 & $0.59^{* *}$ & 61 & $0 \cdot 10$ \\
\hline $\mathrm{CD} \times \mathrm{C} 3 \mathrm{H}$ & 95 & $0.44^{* *}$ & 98 & $0.37 * *$ \\
\hline $\mathrm{CD} \times \mathrm{DBA}$ & 92 & $0.35^{* *}$ & 106 & $0.24^{* *}$ \\
\hline$C D \times F_{1}$ & 118 & $0 \cdot 29 * *$ & 152 & $0.24^{* *}$ \\
\hline $\mathrm{DC} \times \mathrm{C} 3 \mathrm{H}$ & 92 & $0 \cdot 29 * *$ & 100 & $0.41^{* *}$ \\
\hline $\mathrm{DC} \times \mathrm{DBA}$ & 57 & $0.27^{*}$ & 97 & $0.39 * *$ \\
\hline $\mathrm{DC} \times \mathrm{F}_{1}$ & 67 & $0.41^{* *}$ & 113 & $0.46^{* *}$ \\
\hline$F_{3}$ & 170 & $0 \cdot 24^{* *}$ & 141 & $0 \cdot 11$ \\
\hline Mean & 1319 & $0.39 \pm 0.04$ & 1367 & $0.27 \pm 0.04$ \\
\hline$r^{2}$ & & $0 \cdot 15$ & & 0.07 \\
\hline
\end{tabular}

and embryonic genotype apparently increasing it relative to the $\mathrm{C} 3 \mathrm{H}$ embryonic genotype. On Day 18 the DBA maternal and embryonic genotypes both seemed to increase placental weight relative to the $\mathrm{C} 3 \mathrm{H}$ maternal and embryonic genotypes. The effects of maternal genotype seemed to diminish effects of differences among embryonic genotypes on placental weight, particularly on Day 12. For example, within hybrid mothers, the difference in placental weights between backcross offspring sired by $\mathrm{C} 3 \mathrm{H}$ males and those sired by DBA males was significant on Day 18 but not on Day 12. Also, within C3H mothers weights of backcross placentae were intermediate between $F_{1}$ and inbred values on Day 18 but not on Day 12. Furthermore, $F_{2}$ and $F_{3}$ placentae had weights which were intermediate in the total range of weights, a possible effect of segregation, on Day 18 but which did not differ significantly in weight from the largest placentae on Day 12. This apparent failure to show effects of segregation on Day 12 may result from maternal effects on placental weight as discussed by Falconer (1960, p. 61). In the case of $F_{2}$ and $F_{3}$ placentae, if even a small number of genes influenced placental weight, the probability of all these genes of DBA origin segregating together in the $F_{2}$ and $F_{3}$ generations is very low and no substantial reduction in $F_{2}$ and $F_{3}$ means is expected.

These changes in the effects of $\mathrm{C} 3 \mathrm{H}$ and DBA maternal genotypes on placental weight from Days 12 to 18 probably reflect different maternal and embryonic gene effects on the maternal and embryonic components of the placenta and changes in their relative contributions to total placental weight across time. At 12 days of pregnancy the maternally derived decidua is large; at 18 days it is very small compared to the embryonically derived trophoblast and labyrinth (Davies \& Glasser, 1968). It is not surprising, therefore, that the maternal genotype should have a greater effect on placental weight at 12 than at 18 days of gestation. The DBA maternal genotype may produce a smaller decidua at 12 days than the $\mathrm{C} 3 \mathrm{H}$ maternal genotype but permit greater elaboration of the labyrinth by 18 days and regulate the weight of the labyrinth, regardless of embryonic genotype, in a way which the $\mathrm{C} 3 \mathrm{H}$ maternal genotype does not. These presumed properties of the maternal genotype show dominance in the direction of the $\mathrm{C} 3 \mathrm{H}$ genotype. The ability of the DBA embryonic genotype to increase placental weight relative to the $\mathrm{C} 3 \mathrm{H}$ embryonic gentoype may reflect greater trophoblast invasion of the uterine 
stroma and/or greater elaboration of the labyrinth. Whatever the means by which embryonic genotypes influence placental weight there may be heterosis for placental weight because within $\mathrm{C} 3 \mathrm{H}$ mothers, in which embryonic gene effects are not masked, $F_{1}$ embryos had heavier placentae than inbred embryos.

Comparison of genetically similar backcross placentae provides another way to examine effects of gene differences between mothers and embryos, such as $\mathrm{H}-2$ differences, in addition to comparisons of inbred and $\mathrm{F}_{1}$ placentae within inbred mothers. $\mathrm{C} 3 \mathrm{H}$ mice have the $\mathrm{H}-2^{\mathrm{k}}$ haplotype and DBA mice have the $\mathrm{H}-2^{\mathrm{q}}$ haplotype (Green, 1968). If qualitative differences in $\mathrm{H}-2$ antigens between mothers and embryos increase placental weight, then backcross placentae from inbred mothers $(\mathrm{C} 3 \mathrm{H} \times \mathrm{CD}$ and $\mathrm{C} 3 \mathrm{H} \times \mathrm{DC})$ should be heavier than reciprocal backcross placentae from $\mathrm{F}_{1}$ mothers $(\mathrm{CD} \times \mathrm{C} 3 \mathrm{H}$ and $\mathrm{DC} \times \mathrm{C} 3 \mathrm{H})$ : these differences were obtained (Table 3 ) but were significant only at Day $18(P<0.01)$. However, the differences do not simply reflect effects of maternal genotypes because placentae from $\mathrm{C} 3 \mathrm{H}$ mothers were, on average, not different from those of $F_{1}$ mothers (Table 2). Backcross placentae from DBA mothers (DBA $\times$ CD and DBA $\times$ DC) were significantly lighter $(P<0.001)$ than reciprocal backcross placentae from $F_{1}$ mothers $(C D \times D B A$ and $D C \times D B A)$ on Day 12 but significantly heavier $(P<0.01)$ on Day 18. This pattern seems to reflect effects of DBA and $F_{1}$ maternal genotypes (Table 1).

The results on effects of $\mathbf{H}-2$ differences between mothers and embryos are equivocal since they varied with maternal genotype. The results for inbred, hybrid and backcross placentae from $\mathrm{C} 3 \mathrm{H}$ mothers are consistent with the hypothesis that qualitative $\mathrm{H}-2$ antigenic differences between mothers and embryos increase placental weight. However, DBA mothers were similar to strain JU mothers in that placentae of their $F_{1}$ embryos were not heavier than placentae of their inbred embryos(McCarthy, 1965; McLaren, 1967; Hetherington, 1971). When $F_{1}$ embryos derived from inbred strains producing different $\mathrm{H}-2$ antigens have heavier placentae than inbred embryos with the same genotype of mother, it is difficult to know whether increased $F_{1}$ placental weight is due specifically to maternal-embryonic H-2 antigenic differences or to heterosis at many loci. The use of congenic resistant strains specifically tests the effect of maternal-embryonic $\mathrm{H}-2$ differences (or embryonic heterozygosity at the $\mathrm{H}-2$ complex) on otherwise isogenic and homozygous maternal and embryonic backgrounds. The presence of maternal-embryonic $\mathrm{H}-2$ antigenic differences has not resulted in increased placental weight (Finkel \& Lilly, 1971; Hetherington, 1973). The use of reciprocal backcrosses in the present study tests effects of maternal-embryonic H-2 differences on placental weight when embryos are, in general, equally heterozygous. Although backcross placentae from $\mathrm{C} 3 \mathrm{H}$ mothers were heavier than reciprocal backcross from $F_{1}$ mothers, which is consistent with the antigenic hypothesis, weights of reciprocal backcross placentae from DBA and $F_{1}$ mothers reflected the effects of DBA and $F_{1}$ maternal genotype at 12 and 18 days of pregnancy. Clearly genotype-dependent differences in placental weight cannot be accounted for simply by the presence or absence of maternal embryonic H-2 antigenic differences.

The marked effect of embryonic sex on placental weight suggests an effect of the Y-chromosome. It is not possible to tell whether this is a direct effect of a Y-linked gene or genes or an indirect (e.g. hormonally mediated) effect.

Within mating groups, heavy embryos tended to have heavy placentae. The decline in the magnitude of the correlation from 12 to 18 days within some mating groups may reflect placental weight loss late in pregnancy (McLaren, 1965b). That the correlation declined in some groups and not in others may indicate differential placental weight loss. Positive correlations between embryonic weight and placental weight provide no direct information by themselves about the physiological significance of differences in placental weight. Gross placental weight may not adequately measure placental size with respect to function. It now becomes important to examine the relationships among differences in placental weight, placental function and embryonic growth. Embryonic and placental weight can be controlled by manipulating maternal and embryonic genotypes, and this ability should provide a way in which to study the genetic control of placental biology and its relation to embryonic growth.

I thank Dr E. Spaziani for laboratory facilities, Dr J. P. Hegmann and Dr R. C. Roberts for comments on the manuscript, and R. Bodenweiser for help. 


\section{References}

Billington, W.D. (1964) Influence of immunological dissimilarity of mothers and foetus on size of placenta in mice. Nature, Lond. 202, 317-318.

DAvies, J. \& Glasser, S.R. (1968) Histological and fine structural observations on the placenta of the rat Acta anat. 69, 542-608.

FALCONER, D.S. (1960) Introduction to Quantitative Genetics. Oliver and Boyd. Edinburgh.

FINKeL, S. \& LILLY, F. (1971) Influence of histocompatihility between mother and foetus on placental size in mice. Nature, Lond. 234, 102-103.

GreEN, E.L. (Ed.) (1968) Handbook on Genetically Standardized Jax Mice. 2nd edn. The Jackson Laboratory, Bar Harbor.

Hetherington, C.M. (1971) The decidual cell reaction placental weight, foetal weight and placental morphology in the mouse. J. Reprod. Fert. 25, 417-424.

Hetherington, C.M. (1973) The absence of any effect of maternal fetal imcompatibility at the $\mathrm{H}-2$ and $\mathrm{H}-3$ loci on pregnancy in the mouse. J. Reprod. Fert. 33, 135-139.
JAMES, D.A. (1965) Effects of antigenic dissimilarity between mother and foetus on placental size in mice. Nature, Lond. 205, 613-614.

MCCARTHY, J.C. (1965) Genetic and environmental control of foetal and placental growth in the mouse. Anim. Prod. 7, 347-361.

MCCARTHY, J.C. (1968) The effects of inbreeding on birth weight and foetal and placental growth in mice. Genet. Res. 11, 43-49.

MCLAREN, A. (1965a) Genetic and environmental effects on foetal and placental growth in mice. J. Reprod. Fert. 9, 79-98.

MCLAREN, A. (1965b) Placental weight loss late in pregnancy. J. Reprod. Fert. 9, 343-346.

McLaren, A. (1967) Effect of foetal mass on gestation period in mice. $J$. Reprod. Fert. 13, 349-351.

SOKAL, R.R. \& ROHLF, F.J. (1969) Biometry. W. H. Freeman, New York.

ThEILER, K. (1972) The House Mouse. Springer-Verlag, Berlin.

Received 20 February 1978 